\title{
Penerapan Pendekatan Kontekstual Berbantuan Media untuk Peningkatan Kualitas Pembelajaran IPS
}

\author{
WIEN MURNIATI dan SUGIHARSONO \\ SMPN 1 Wiradesa, Universitas Negeri Yogyakarta \\ wienmurni@yahoo.co.id , sugiharsono@gmail.com
}

\begin{abstract}
Abstrak
Penelitian ini bertujuan (1) menerapkan pendekatan kontekstual berbantuan media (2) me ngetahui peningkatan kualitas pembelajaran, (3) menemukan kendala dan pendorong. Metode penelitian menggunakan penelitian tindakan kelas. Subjek penelitian 28 siswa kelas VIII.5 SMPN 1 Wiradesa tahun pelajaran 2013/2014. Teknik pengumpulan data meliputi: observasi, angket, wawancara, tes, dan dokumentasi. Hasil penelitian menunjukkan peningkatan kualitas proses pembelajaran pada pratindakan 1,68 (Kurang), siklus I 2,98 (Baik), dan siklus II 3,72 (Sangat Baik). Kualitas hasil belajar menunjukkan peningkatan: (1) ranah kognitif, pratindakan rerata nilai 76,43 dan ketuntasan kelas 46\%, siklus I 85,17 dan 89\%, siklus II 88,84 dan 93\%, (2) ranah afektif, siklus I rerata nilai 79 (Baik) dan siklus II 82 (Baik), (3) ranah psikomotorik, siklus I rerata nilai 84 (Baik) dan siklus II 98 (Sangat Baik), dalam penerapannya tidak ada kendala yang berarti dengan didukung input siswa dan lingkungan sekolah yang baik.
\end{abstract}

Kata Kunci: pendekatan kontekstual, media, kualitas pembelajaran

\begin{abstract}
This research aims to (1) apply a media assisted contextual approach (2) know the improvement of learning quality, and (3) find obstacles and the supporting elements. The research utilizes a classroom action research method. The subjects of the research include 28 students of grade VIII.5 at SMPN 1 Wiradesa academic year of 2013/2014. The data collection techniques consist of: observations, questionnaires, interviews, tests, and documentations. The findings show that the improvement of the learning quality occurs on the pre-action, that is 1.68 (poor), the first cycle is 2.98 (Good), and the second cycle is 3.72 (Very Good). The learning quality undergoes improvements in: (1) cognitive domain, the pre-action mean score is 76.43 and the mastery of the class is $46 \%$, in the first cycle is 89 and $85.17 \%$, in the second cycle is 88.84 and 93\%, (2) affective domain, the mean score of the first cycle is 79 (Good) and the second cycle is 82 (Good), (3) the psychomotor domain, the mean score of the first cycle is 84 (Good) and the second cycle is 98 (Very Good). In practice, there are no significant obstacles since the learning is supported by students' input and good school environment.
\end{abstract}

Keywords: contextual approach, media, the learning quality 


\section{PENDAHULUAN}

Lemahnya proses pembelajaran merupakan salah satu masalah yang dihadapi dunia pendidikan kita. Dalam proses pembelajaran, anak kurang didorong untuk mengembangkan kemampuan berpikir. Proses pembelajaran di dalam kelas diarahkan kepada kemampuan anak untuk menghafal informasi; otak anak dipaksa untuk mengingat dan menimbun berbagai informasi tanpa dituntut untuk memahami informasi yang diingatnya itu untuk menghubungkannya dengan kehidupan sehari-hari. Akibatnya, ketika anak didik kita lulus dari sekolah, mereka pintar secara teoritis, akan tetapi mereka miskin aplikasi (Sanjaya, 2010, p.xiii). Pernyataan ini juga diperkuat oleh pendapat Muslich (2009, p.40), bahwa sebagian besar peserta didik tidak mampu menghubungkan antara apa yang mereka pelajari dengan bagaimana pemanfaatannya dalam kehidupan nyata. Hal ini karena pemahaman konsep yang mereka peroleh hanyalah merupakan sesuatu yang abstrak, belum menyentuh kebutuhan praktis kehidupan mereka, baik dilingkungan kerja maupun di masyarakat. Pembelajaran yang selama ini mereka terima hanyalah penonjolan tingkat hafalan dari sekian topik atau pokok bahasan, tetapi kurang diikuti dengan pemahaman atau pengertian yang mendalam, yang bisa diterapkan ketika mere ka berhadapan dengan situasi baru dalam kehidupannya.

Paradigma pendidikan memandang bahwa anak akan belajar lebih baik jika lingku ngan diciptakan alamiah. Didukung pendapat para pakar teori kognisi yang menekankan pentingnya peserta didik untuk melihat dan mempunyai pengalaman langsung mengenai konsep dan kemampuan tertentu dalam pembelajaran. Untuk mewujudkan hal tersebut, diperlukan kegiatan pembelajaran yang menyeluruh dan melibatkan beberapa komponen yaitu peserta didik, guru, tujuan pembelajaran, isi pelajaran, media pembelajaran, pendekatan, metode, dan strategi, serta penilaian kemajuan belajar. Penggunaan pendekatan, metode, dan strategi yang tepat merupakan unsur yang sangat signifikan un- tuk dapat menciptakan pembelajaran yang aktif, kreatif dan interaktif.

Berdasarkan pengamatan peneliti ketika melaksanakan observasi di SMP N 1 Wiradesa, dalam proses pembelajaran kurang melibatkan peserta didik secara aktif dan tidak kontekstual. Guru belum menerapkan model pembelajaran yang sesuai dengan materi yang diajarkan, media yang ada pun belum dioptimalkan penggunaannya dan kurang bervariasi, yaitu hanya menggunakan power point. Peserta didik tidak dibiasakan untuk belajar secara kooperatif dan kolaboratif, sehingga kurang kerjasama di antara me reka dalam memecahkan masalah maupun mengatasi kesulitan belajar. Proses pembelajaran seperti ini berakibat pada rendahnya kualitas pembelajaran. Pembelajaran menjadi kurang bermakna, dan minimnya kompetensi yang dikuasai peserta didik sehingga berdampak pada rendahnya hasil belajar. Hal ini dibuktikan dari rata-rata nilai ulangan harian mata pelajaran IPS yang lebih rendah dari KKM (78). Rata-rata nilai ulangan harian pertama kelas VIII.5 pada semester gasal tahun pelajaran 2012/2013 adalah 76,43, peserta didik yang tuntas dari 28 anak hanya 13 anak (46\%), dan 15 anak (54\%) belum tuntas. Seharusnya kondisi seperti ini tidak terjadi, mengingat SMPN 1 Wiradesa merupakan SMP yang paling favorit di Kabupaten Pekalongan (eks SMP RSBI) dengan fasilitas yang cukup lengkap, tentunya input peserta didik pun cukup baik. Fenomena tersebut merupakan indikator rendahnya kualitas pembelajaran.

Salah satu bentuk pendekatan pembelajaran IPS yang diduga tepat dan mempunyai orientasi terhadap proses serta hasil belajar adalah menggunakan pendekatan kontekstual. Pembelajaran kontekstual atau contextual teaching and learning (CTL) menurut Berns \& Erickson (2001: 2), contextual teaching and learning is a conception of teaching and learning that help teachers relate subject matter content to real world situations; and motivates students to make connections between knowledge and its applications to their lives as family members, citizens, and workers and engage in the hard work that learning requires. Per- 
nyataan tersebut menyebutkan bahwa pembelajaran kontekstual merupakan konsep belajar dan mengajar yang membantu guru mengaitkan antara materi yang diajarkannya dengan situasi dunia nyata peserta didik dan mendorong peserta didik membuat hubu ngan antara pengetahuan yang dimilikinya dengan penerapannya dalam kehidupan mereka sebagai anggota keluarga, warga ne gara, dan pekerja. Pendekatan kontekstual ini merupakan pendekatan yang dapat menguatkan, memperluas dan menerapkan pengetahuan serta keterampilan akademik peserta didik dalam berbagai macam tatanan baik di sekolah maupun di luar sekolah. Selain itu peserta didik dilatih untuk dapat memecahkan masalah yang mereka hadapi dalam bentuk simulasi dan masalah yang memang ada di dunia nyata. Apabila CTL diterapkan de ngan benar, diharapkan peserta didik akan terlatih untuk dapat menghubungkan apa yang diperoleh di kelas dengan kehidupan nyata yang ada di lingkungannya.

Sementara itu Hull's \& Sounders (Komalasari, 2011: 6) menjelaskan: in a Contextual Teaching and Learning (CTL), student discover meaningful relationship between abstract ideas and practical applications in a real world context. Students internalize concepts through discovery, reinforcement, and interrelationship. CTL creates a team, whether in the classroom, lab, worksite, or on the banks of river. CTL encourages educators to design learning environments that incorporate many forms of experience to achieve the desired outcomes. Pernyataan ini menunjukkan bahwa di dalam pembelajaran kontekstual, peserta didik menemukan hubungan penuh makna antara ide-ide abstrak dengan penerapan praktis di dalam konteks dunia nyata. Peserta didik menginternalisasi konsep melalui penemuan, penguatan, dan keterhubungan. Pembelajaran kontekstual menghendaki kerja dalam sebuah tim, baik di kelas, laboratorium, tempat bekerja maupun bank. Pembelajaran kontekstual menuntut guru mendesain lingkungan belajar yang merupakan gabu ngan beberapa bentuk pengalaman untuk mencapai hasil yang diinginkan.

Pendekatan kontekstual dalam pembela- jaran IPS merupakan inovasi strategi pembelajaran IPS yang diharapkan dapat digunakan sebagai sarana untuk mengorganisasi dan melatih sikap ilmiah peserta didik, karena melalui kegiatan tersebut peserta didik dilatih untuk mau dan mampu berbuat untuk meningkatkan interaksi dengan lingkungan fisik dan sosialnya, sehingga mampu membangun pemahaman dan pengetahuannya terhadap dunia di sekitarnya (learning to know), belajar untuk terampil dalam melakukan sesuatu (learning to do), dari hasil inte raksi dengan lingkungan diharapkan dapat membangun kepercayaan diri learning to be), dan kesempatan berinteraksi dengan berbagai individu atau kelompok individu yang bervariasi (learning to live together) akan membentuk kepribadiannya untuk memahami kemajemukan dan melahirkan sikap positif dan toleransi terhadap keane karagaman perbedaan hidup yang ada di masyarakat. Disamping itu, pembelajaran kontekstual dapat menggabungkan antara gerakan fisik dengan aktivitas intelektual dan semua indera peserta didik sehingga proses pembelajaran dapat berlangsung dengan aktif, kreatif dan menyenangkan.

Sanjaya (2010: 264) merekomendasikan tujuh asas atau komponen yang melandasi proses pembelajaran IPS dengan menggunakan pendekatan kontekstual yaitu: kontruktivisme (constructivism), menemukan (inquiry), bertanya (questioning), masyarakat belajar (learning community), pemo delan (modeling), refleksi (reflection), dan penilaian sebenarnya (autentic assessment). Komponen-komponen tersebut yang akan diterapkan oleh guru pada kegiatan pembelajaran di kelas.

Salah satu upaya untuk mendukung keberhasilan penerapan model pembelajaran kontekstual ini perlu penggunaan media pembelajaran yang tepat. Sukiman (2012: 29) menyatakan bahwa media adalah segala sesuatu yang dapat digunakan untuk menya lurkan pesan dari pengirim ke penerima sehingga merangsang pikiran, perasaan, perhatian dan minat serta kemauan peserta didik sedemikian rupa sehingga proses belajar terjadi dalam rangka mencapai tujuan pembela- 
jaran secara efektif.

Media yang digunakan hendaknya sesuai dengan karakteristik materi yang diajarkan, sehingga dapat meningkatkan pemahaman peserta didik, penyajian data/informasi menjadi lebih menarik dan terpercaya, memudahkan penafsiran data, dan memadatkan informasi. Sependapat dengan itu Solihatin \& Raharjo (2011: 25) mengatakan bahwa penggunaan media bukan hanya membuat proses pembelajaran lebih efisien, tetapi juga membantu peserta didik menyerap materi belajar lebih mendalam dan utuh. Apabila hanya dengan mendengarkan informasi verbal dari guru, peserta didik mungkin kurang memahami pelajaran dengan baik. Akan tetapi, jika hal itu diperkaya dengan melihat, menyentuh, merasakan, atau mengalami sendiri melalui media maka pemahaman pesrta didik pasti akan lebih baik. Dengan demikian pembelajaran menjadi bermakna yang pada akhirnya akan berdampak pada meningkatnya hasil belajar (kualitas pembelajaran meningkat).

Kualitas pembelajaran menurut Mulyasa (2008: 101) dapat dilihat dari segi proses dan hasil. Dari segi proses, pembelajaran atau pembentukan kompetensi dikatakan berhasil dan berkualitas apabila seluruh atau setidak-tidaknya sebagian besar (75\%) peserta didik terlibat secara aktif, baik fisik, mental, maupun sosial dalam proses pembelajaran, di samping menunjukkan kegiatan belajar yang tinggi, semangat belajar yang besar, dan rasa percaya pada diri sendiri. Sedangkan dari segi hasil pembelajaran dikatakan berhasil apabila terjadi perubahan perilaku yang positif pada diri peserta didik seluruhnya atau sebagian besar $(75 \%)$.

Secara rinci Widoyoko (2013: 236) mengemukakan kualitas pembelajaran IPS dapat dinilai dari beberapa komponen yaitu: (1) kinerja guru yang meliputi penguasaan konsep/materi IPS, pemahaman karakteris tik peserta didik, penguasaan pengelolaan pembelajaran, penguasaan strategi pembelajaran, dan penguasaan penilaian hasil belajar; (2) fasilitas pembelajaran yang meliputi kondisi ruang pembelajaran, kelengkapan media pembelajaran IPS, kondisi media pembelajaran IPS, dan kelengkapan sumber-sumber belajar IPS; (3) iklim kelas, antara lain keter libatan peserta didik dalam pembelajaran, kepuasan peserta didik mengikuti kegiatan pembelajaran IPS dan dukungan guru dalam pembelajaran IPS; (4) sikap peserta didik yang terdiri dari pemahaman manfaat IPS (kognisi), rasa senang terhadap IPS (afeksi) dan kecenderungan bertindak dalam pembelajaran IPS (konasi); (5) motivasi belajar peserta didik yang meliputi orientasi pada keberhasilan, antisipasi kegagalan, inovasi, dan tanggung jawab.

Kualitas pembelajaran IPS dari berbagai pengertian tersebut, ditunjukkan dengan ada nya penataan komponen masukan instrumental dan masukan potensial sedemikian rupa, sehingga secara sinergis mampu menghasilkan proses, hasil, dan dampak belajar yang optimal.

Beberapa penelitian yang mendukung tentang penggunaan pendekatan konteks tual berbantuan media antara lain penelitian yang dilakukan oleh Setyati (2011: 71-77) berjudul "Peningkatan Aktivitas dan Hasil Belajar Kalor melalui Pendekatan Kontekstual berbantuan Concept Cartoon bagi Siswa Kelas VII.6 SMP 2 Blora Semester Genap Tahun Pelajaran 2010/2011 menunjukkan bahwa penggunaan pendekatan kontekstual berbantuan concept cartoon dapat meningkatkan aktivitas dan hasil belajar kalor. Selain itu pendekatan kontekstual berbantuan concept cartoon merupakan teknik pembelajaran yang menyenangkan bagi peserta didik sehingga mampu menumbuhkan motivasi belajar peserta didik. Harimurti (2011: 33-41) dalam penelitian yang berjudul "Pendekatan Kontekstual dengan Teknik Rangsang Gambar dalam Upaya Meningkatkan Kemampuan Bercerita", menyimpulkan bahwa pembelajaran melalui pendekatan kontekstual dengan teknik rangsang gambar dapat meningkatkan aktivitas belajar, kemampuan bercerita peserta didik, serta kinerja guru dalam pembelajaran dari siklus I dan siklus II.

Berdasarkan kajian teori dan kajian hasil penelitian yang relevan, pemecahan permasalahan kelas pada penelitian ini sebagai berikut: (1) penerapan pendekatan konteks tual dalam pembelajaran IPS akan 
meningkatkan kualitas pembelajaran. Pembelajaran kontekstual (Contextual Teaching and Learning/CTL) lebih menekankan kepada proses keterlibatan peserta didik secara penuh untuk dapat menemukan dan membangun penge tahuan yang dipelajari dan menghubungkan nya dengan situasi kehidupan nyata. Proses pembelajaran akan berlangsung alamiah dalam bentuk peserta didik bekerja dan mengalami, bukan sekedar transfer pengetahuan dari guru ke peserta didik. Pembelajaran menjadi bermakna karena menyediakan kesempatan yang luas kepada peserta didik dalam mengungkapkan pendapat dan pertanyaan, baik dalam kelompok belajar ataupun kelas dalam suasana yang interaktif, res ponsif, dan kreatif. Aktivitas peserta didik mendominasi dalam pembelajaran (student centered) sehingga kualitas pembelajaran ditinjau dari prosesnya akan meningkat; (2) pembelajaran IPS dengan pendekatan kontekstual akan lebih bermakna manakala digunakan media pembelajaran yang sesuai dengan karakteristik materi pelajaran. Penggunaan media power point, kartu, bagan, gambar, dan pasar akan membuat peserta didik lebih mudah memahami materi yang dipelajarinya. Dengan berbantuan media tersebut akan mengatasi keterbatasan indra, ruang, dan waktu, serta memperjelas penyajian pesan dan informasi. Dengan kata lain dapat membantu memberikan penjelasan materi pelajaran yang bersifat abstrak menjadi lebih konkret, sehingga dapat merangsang perhatian, minat, pikiran, dan perasaan peserta didik dalam belajar untuk mencapai tujuan belajar. Penerapan pembelajaran kontekstual dengan bantuan media kartu, bagan, gambar, dan pasar membuat materi pelajaran mudah dipahami dan mengendap lama pada memory peserta didik. Hal ini akan berdampak pada peningkatan hasil belajar peserta didik.

Tujuan yang akan dicapai dalam penelitian ini adalah: (1) menerapkan pendekatan kontekstual dengan bantuan media power point, kartu, bagan, gambar dan pasar dalam pembelajaran IPS di SMPN 1 Wiradesa, (2) mendapatkan bukti empirik peningkatan kualitas pembelajaran IPS dilihat dari proses dan hasil belajar peserta didik, (3) menemukan faktor-faktor yang menjadi kendala dan pendorong dalam penerapannya.

\section{METODE}

Penelitian ini merupakan penelitian tindakan kelas yang dilaksanakan pada tahun pelajaran 2013/2014 semester I selama 3 bulan (Agustus sampai dengan Oktober 2013). Penelitian dilaksanakan secara alami sejalan dengan proses pembelajaran yang berlangsung, yaitu 4 jam pelajaran (@40 menit/jam pelajaran), di SMPN 1 Wiradesa Kabupaten Pekalongan pada kelas VIII.5 yang berjumlah 28 anak, terdiri atas 10 laki-laki dan 18 perempuan dengan karakteristik kemampuan yang heterogen. Penelitian melibatkan guru mata pelajaran IPS kelas VIII.5 yang berperan sebagai kolaborator sekaligus pelaksana tindakan. Sementara itu, peneliti berperan sebagai desainer dan pengamat tindakan. Desain penelitian menggunakan model yang dikembangkan oleh Kemmis \& Mc Taggart yang mencakup sejumlah siklus, antara satu siklus dengan yang lainnya saling terkait yang terus berulang sampai dengan tujuan penelitian tercapai. Setiap siklus meliputi tiga tahap yaitu:

Pertama, Perencanaan tindakan (planning), kegiatan yang dilakukan meliputi: (a) membuat perencanaan pembelajaran, (b) melakukan koordinasi dengan kolaborator dan memberikan berbagai macam penjelasan mengenai teknis pelaksanaan kegiatan penelitian, (c) menyiapkan perangkat pembelajaran yang sudah dikembangkan seperti silabus, rencana pelaksanaan pembelajaran (RPP), kisi-kisi, soal tes/ulangan harian, dan kunci jawaban tes, (d) merancang dan menyi apkan metode, sumber belajar, media/alat pembelajaran dan bahan diskusi.

Kedua, Pelaksanaan tindakan (action) dan pengamatan (observation). Tindakan yang dilakukan adalah menerapkan pendekatan kontekstual dengan bantuan media dalam pembelajaran IPS dengan menerapkan tujuh komponen pendekatan kontekstual yang meliputi konstruktivisme (constuctivism), bertanya (questioning), menemukan (inquiry), 
masyarakat belajar (learning community), pemodelan (modeling), refleksi (reflectioning), dan penilaian autentik (authentic assessment). Observasi dilakukan oleh peneliti dengan dibantu oleh kolaborator (guru IPS) selama proses pembelajaran berlangsung. Pengamatan dilakukan untuk mengetahui proses pembelajaran yang meliputi kinerja guru dan iklim kelas (aktivitas peserta didik).

Ketiga, Refleksi (reflection), digunakan peneliti untuk mengkaji mengenai apa yang telah dilaksanakan, bagaimana hasilnya, apakah sudah sesuai dengan yang direncanakan, atau karena adanya kekurang tepatan dalam menyusun rencana sehingga hasilnya tidak sesuai dengan yang diharapkan. Apabila tahapan yang sudah dilaksanakan tersebut belum sesuai dengan indikator keberhasilan penelitian, maka tindakan penelitian dilanjutkan pada siklus berikutnya de ngan mengakomodasi berbagai temuan yang muncul pada kegiatan refleksi untuk diadakan perbaikan, baik dalam menyusun perencanaan pembelajaran maupun pelaksanaan tindakan.

Teknik pengambilan data yang digunakan berbentuk nontes (observasi, angket, wawancara, dan dokumentasi) serta tes hasil belajar. Observasi dilakukan terhadap kinerja guru dan aktivitas peserta didik (iklim kelas) dalam pembelajaran IPS. Pedoman observasi kinerja guru berisi pernyataan yang menunjukkan proses pembelajaran secara ideal yang mengacu pada standar proses dengan penerapan tujuh komponen pendekatan kontekstual berbantuan media pembelajaran. Sedangkan pedoman observasi iklim kelas berisi pernyataan keaktivan peserta didik selama mengikuti pembelajaran IPS meliputi: (1) kesiapan mengikuti pelajaran IPS, (2) perhatian terhadap pembelajaran IPS, (3) membentuk kelompok yang efektif dan efisien, (4) aktif melakukan kegiatan dalam kelompok, (4) keberanian bertanya pada guru/teman, (5) keberanian menjawab pertanyaan, (6) mengerjakan soal/tugas/ latihan, (6) keberanian mempresentasikan hasil belajar, (7) melakukan refleksi terhadap pembelajaran, (8) membuat rangkuman pelajaran
Angket untuk peserta didik berisi pernyataan untuk menggali kecakapan sosial dan sikap peserta didik terhadap pembelajaran IPS dengan pendekatan kontekstual berbantuan media. Angket kecakapan sosial terdiri atas 3 butir pernyataan yang mencerminkan sikap sosial yang dimiliki oleh peserta didik dalam melaksanakan kerja kelompok yaitu: kerja sama, tanggung jawab, dan tenggang rasa. Ketiga kecakapan sosial tersebut, masing-masing peserta didik dinilai oleh dua teman sejawat dalam satu kelompoknya. Ins trumen sikap peserta didik terhadap pembelajaran IPS terdiri atas 3 indikator sikap yang dikembangkan menjadi 15 butir pernyataan yang meliputi tiga indikator yaitu: memandang penting pelajaran IPS (5 butir), menyenangi pembelajaran IPS ( 5 butir), dan memandang penting penggunaan media pembelajaran ( 5 butir). Angket untuk guru berupa pertanyaan terbuka, jawaban tidak disediakan sehingga guru bebas menuliskan jawaban sesuai dengan yang dialami dan dirasakannya. Angket ini digunakan sebagai pendukung data kinerja guru. Wawancara dilakukan secara individual terhadap peserta didik untuk mengetahui tanggapan serta kesan peserta didik secara langsung terhadap proses pembelajaran IPS dengan pendekatan kontekstual berbantuan media. Wawancara digunakan sebagai pelengkap data penelitian dan dilaksanakan dengan metode tidak terstruktur, oleh karena itu pertanyaan yang disampaikan tergantung pada situasi yang ada. Tes hasil belajar dilakukan secara tertulis pada setiap akhir siklus kegiatan penelitian dalam bentuk soal-soal pilihan ganda. Dokumentasi dalam penelitian ini berkaitan dengan dokumen-dokumen yang berupa daftar nilai pratindakan, hasil pekerjaan/tugastugas peserta didik, dan foto-foto kegiatan pembelajaran. Data tersebut dihimpun dan dianalisis untuk mengetahui kualitas pembelajaran dan sebagai bahan pertimbangan manakala perlu adanya tindakan siklus berikutnya.

Pada penelitian ini digunakan teknik analisis deskriptif, yaitu analisis yang menggambarkan kenyataan atau fakta sesuai de ngan data yang diperoleh yang diklasifika- 
sikan menurut kategorinya dengan tujuan untuk mengetahui kualitas proses pembelajaran dan hasil belajar yang dicapai serta respon peserta didik terhadap kegiatan pembelajaran IPS.

\section{HASIL DAN PEMBAHASAN}

Hasil penelitian diperoleh dari hasil pelaksanaan tindakan yang dilakukan materi standar kompetensi 4 yaitu memahami kegiatan pelaku ekonomi di masyarakat yang terdiri atas dua siklus. Pelaksanaan tindakan dilakukan dengan menggunakan pendekatan kontekstual berbantuan media powerpoint, kartu, bagan, dan gambar, serta pada siklus II ditambah dengan pasar. Sebelum dilakukan tindakan, Peneliti melakukan kegiatan pratindakan untuk mengetahui permasalahan dan kondisi subjek yang sebenarnya agar dapat merencanakan tindakan yang tepat.

Pratindakan

Berdasarkan dokumen tes hasil belajar IPS pada ulangan harian yang pertama semester ganjil tahun pelajaran 2013/2014 menunjukkan kualitas hasil belajar kelas VIII.5 dalam kategori cukup. Rata-rata nilai ulangan masih di bawah KKM (Kriteria Ketuntasan Minimal). KKM yang ditetapkan untuk pelajaran IPS adalah 78, siswa yang tuntas belajar masih di bawah 50\%, dari 28 anak hanya 13 anak (46\%) yang tuntas, dan 6 anak (54\%) belum tuntas, sedangkan ratarata nilai ulangan 76,43. Nilai tertinggi 93 dan terendah 53.

Berdasarkan hasil observasi, Guru dalam pembelajaran masih menggunakan cara konvensional (teacher centered), belum menerap kan pendekatan kontekstual namun sudah menggunakan bantuan media power point. Proses pembelajaran berlangsung dengan cara guru menerangkan materi pelajaran dengan slide yang ditayangkan melalui LCD, peserta didik mendengarkan dan mencatat materi yang dianggap penting. Adakalanya guru menanyakan sesuatu hal yang berkaitan dengan materi kepada peserta didik dan memberikan kesempatan kepada peserta didik untuk menanyakan materi yang belum dipahami. Guru tidak melakukan penilaian dalam proses pembelajaran.

Kinerja guru dalam pembelajaran masih kurang dengan rerata skor 1,76. Kemampuan guru dalam membuka dan menutup pembelajaran menunjukkan rerata skor 2,33 (Cukup). Penggunaan media pembelajaran juga dalam kategori "Cukup" $(2,50)$. Penerapan tujuh komponen kontekstual belum begitu tampak dengan rerata skor 1,47 (Sangat Kurang). Empat komponen yaitu konstruktvisme, inkuiri, masyarakat belajar, dan penilaian autentik masih "Sangat kurang", sedangkan tiga komponen yang lain yaitu bertanya, pemodelan dan refleksi dalam kate gori "Kurang".

Pengamatan terhadap keaktivan peserta didik tercermin pada Iklim kelas diperoleh nilai rerata 1,60 yang berarti menggambarkan keadaan kelas "Sangat kurang" kondusif. Kesiapan peserta didik dalam mengikuti pelajaran sudah tergolong "Baik", perhatian peserta didik terhadap pembelajaran IPS tergolong "Cukup". Kemauan peserta didik untuk membentuk kelompok yang efektif dan efisien serta keaktivan dalam kelompok masih "Kurang". Keberanian peserta didik dalam bertanya kepada guru dan menjawab perta nyaan juga masih "Kurang". Keaktivan peserta didik mengerjakan soal atau tugas sudah "Baik", namun keberanian peserta didik untuk mempresentasikan hasil belajar dan melakukan refleksi terhadap pembelajaran masih "Kurang". Sedangkan untuk membuat rangkuman pembelajaran tergolong "Cukup".

Berdasarkan hasil pengamatan terhadap kinerja guru dan iklim kelas, kualitas proses pembelajaran pada pratindakan menunjukkan rerata skor 1,68 dengan kategori "Kurang". Secara ringkas kualitas proses pembelajaran disajikan pada tabel berikut.

\section{Tabel 1. Penilaian Kualitas Proses Pembelajaran Pratindakan}

\begin{tabular}{lcc}
\hline \multicolumn{1}{c}{ Aspek } & Rerata Skor & Kategori \\
\hline Kinerja guru & 1,76 & Kurang \\
Iklim Kelas & 1,6 & Sangat Kurang \\
Rerata & 1,68 & Kurang \\
\hline
\end{tabular}




\section{Hasil Siklus I \\ Kualitas Proses Pembelajaran Siklus I}

Kualitas proses pembelajaran dalam penelitian ini dilihat dari kinerja guru dan iklim kelas (keaktivan peserta didik) melalui pengamatan. Pengamatan terhadap kinerja guru dalam siklus I diperoleh rerata skor 3,10 dengan kategori "Baik". Kinerja guru tersebut meliputi: (1) Kemampuan guru dalam membuka dan menutup pembelajaran diperoleh rerata skor 3,58 (Sangat Baik); (2) Kemampuan guru dalam menerapkan 7 komponen pendekatan kontekstual diperoleh rerata skor 2,94 (Baik). Dari 7 komponen tersebut kemampuan tiap komponennya beragam. Refleksi dan penilaian autentik sudah menunjukkan kategori "Sangat Baik", kons truktivisme dan pemodelan menunjukkan kategori "Baik", sedangkan inkuiri, bertanya dan masyarakat belajar masih menunjukan kategori "Cukup"; (3) Keefektifan penggunaan media pembelajaran diperoleh rerata skor 3,00 (Baik).

Iklim kelas dilihat dari keaktivan peserta didik dalam proses pembelajaran IPS dengan menggunakan pendekatan kontekstual power point, kartu, bagan, dan gambar, pada siklus I sudah terlihat "Baik" dengan rerata skor 2,85. Kesiapan peserta didik dalam mengikuti pelajaran "Baik", perhatian peserta didik terhadap pembelajaran IPS sudah "Baik", sebagian besar peserta didik dapat membentuk kelompok belajar yang efektif dan efisien serta aktif dalam kelompok belajar (Baik). Rata-rata keberanian peserta didik dalam bertanya kepada guru dan menjawab pertanyaan sudah mulai tampak (Kurang). Semua peserta didik sudah terlihat aktif mengerjakan soal atau tugas (Sangat Baik), rata-rata peserta didik mulai berani untuk mempresentasikan hasil belajar (Kurang), dan sebagian besar peserta didik melakukan refleksi terhadap pembelajaran yang baru saja dilaksanakan (Baik), serta peserta didik sudah membuat rangkuman materi pelajaran (Sangat Baik).

Kualitas proses pembelajaran pada siklus I berdasarkan penggabungan hasil penilaian terhadap kinerja guru dan iklim kelas diperoleh rerata skor 2,98 dengan kategori "Baik". Secara ringkas kualitas proses pembelajaran disajikan pada tabel berikut.

\section{Tabel 2. Penilaian Kualitas Proses Pembelajaran Siklus I}

\begin{tabular}{ccc}
\hline Aspek & Rerata Skor & Kategori \\
\hline Kinerja guru & 3,10 & Baik \\
Iklim Kelas & 2,85 & Baik \\
Rerata & 2,98 & Baik \\
\hline
\end{tabular}

\section{Kualitas Hasil Belajar Siklus I}

Peningkatan kualitas hasil belajar secara komprehensif setelah diterapkan pendekatan kontekstual dengan bantuan media power point, kartu, bagan, dan gambar dalam pembelajaran IPS meliputi tiga ranah yaitu kognitif, afektif dan psikomotrik. Peningkatan ketiga ranah tersebut sebagai berikut.

Hasil belajar ranah kognitif diperoleh dari penilaian tugas individual dan tes hasil belajar. Rerata nilai tugas individual menunjukkan 88,10 atau "Baik", dengan peserta didik yang tuntas sebesar 89\%, nilai tertinggi 100 dan nilai terendah 75 .

Tes hasil belajar peserta didik pada siklus I diperoleh rata-rata nilai ulangan sudah melampaui KKM yaitu 83,21 (Baik). Namun secara klasikal belum mencapai ketuntasan, karena dari 28 anak, yang tuntas belajar 22 anak (79\%), dan 6 anak (21\%) belum tuntas. Nilai tertinggi 95 dan nilai terendah 55.

Hasil belajar ranah kognitif merupakan penggabungan dari penilaian tugas individual (40\%) dan ulangan harian (60\%) diperoleh nilai rerata kelas sudah melampaui KKM yaitu sebesar 85,17 dan ketuntasan kelas juga sudah tercapai yaitu 89\%. Hasil belajar ranah kognitif secara ringkas disajikan dalam tabel berikut. 
Tabel 3. Rekapitulasi Hasil Belajar Ranah Kognitif Siklus I

\begin{tabular}{cccc}
\hline Kategori & Interval Nilai & Frekuensi (f) & Persentase (\%) \\
\hline Sangat Baik & $90-100$ & 8 & 28 \\
Baik & $78-89$ & 17 & 61 \\
Cukup & $67-77$ & 3 & 11 \\
Kurang & $55-66$ & & \\
Sangat Kurang & $<55$ & 28 & 100 \\
Jumlah & & 100 & \\
Nilai Tertinggi & 70 & \\
Nilai Terendah & 85,17 & \\
Rerata & $89 \%$ & \\
Ketuntasan & &
\end{tabular}

Penilaian hasil belajar ranah afektif dilakukan secara autentik meliputi kecakapan sosial dan sikap peserta didik terhadap pembelajaran IPS. Kecakapan sosial peserta didik diperoleh rerata nilai 76 dengan kategori "Cukup". Secara ringkas hasil penilaian kecakapan sosial peserta didik disajikan pada tabel berikut.

Tabel 4. Rekapitulasi Penilaian Kecakapan Sosial Siklus I

\begin{tabular}{lcc}
\hline \multicolumn{1}{c}{ Aspek } & $\begin{array}{c}\text { Rerata } \\
\text { Nilai }\end{array}$ & Kategori \\
\hline Kerja sama & 78 & Baik \\
Tanggung jawab & 74 & Cukup \\
Tenggang rasa & 78 & Baik \\
Rerata & 76 & Cukup \\
\hline
\end{tabular}

Sikap peserta didik terhadap pembelajaran IPS diukur dari angket yang diisi oleh peserta didik diperoleh hasil "Baik" dengan rerata nilai 82 . Sikap peserta didik terhadap pembelajaran IPS secara ringkas ditunjukkan pada tabel berikut.
Tabel 5. Rekapitulasi Penilaian Sikap Peserta Didik terhadap Pembelajaran IPS Siklus I

\begin{tabular}{lcc}
\hline \multicolumn{1}{c}{ Indikator } & $\begin{array}{c}\text { Rerata } \\
\text { Nilai }\end{array}$ & Kategori \\
\hline $\begin{array}{l}\text { Memandang penting } \\
\text { pelajaran IPS }\end{array}$ & 82 & Baik \\
$\begin{array}{l}\text { Menyenangi } \\
\text { pembelajaran IPS }\end{array}$ & 81 & Baik \\
$\begin{array}{l}\text { Memandang penting } \\
\text { penggunaan media } \\
\text { pembelajaran }\end{array}$ & 83 & Baik \\
\begin{tabular}{l} 
Rerata \\
\hline
\end{tabular} & 82 & Baik \\
\hline
\end{tabular}

Hasil belajar ranah afektif merupakan penggabungan penilaian kecakapan sosial dan sikap peserta didik terhadap pembelajaran IPS maka diperoleh rerata nilai sebesar 79 (Baik). Hasil Belajar ranah afektif secara ringkas disajikan pada tabel berikut. 
Tabel 6. Rekapitulasi Hasil Belajar Ranah Afektif Siklus I

\begin{tabular}{cccc}
\hline Kategori & Interval Nilai & Frekuensi (f) & Persentase (\%) \\
\hline Sangat Baik & $90-100$ & 3 & 10 \\
Baik & $78-89$ & 12 & 43 \\
Cukup & $67-77$ & 12 & 43 \\
Kurang & $55-66$ & 1 & 4 \\
Sangat Kurang & $<55$ & & 100 \\
Jumlah & & 28 & \\
Nilai Tertinggi & 92 & \\
Nilai Terendah & 61 & \\
Rerata & 79 & \\
Kategori & Baik &
\end{tabular}

Selama proses pembelajaran siklus I, guru melaksanakan penilaian autentik melalui kerja kelompok (ranah psikomotorik). Kerja kelompok sebanyak tiga kali yaitu: mengklasifikasikan 10 macam kebutuhan, mengklasifikasikan gambar alat pemuas kebutuhan, dan menyusun skala prioritas kebutuhan. Dari penilaian ketiganya diperoleh rerata skor 84 (Baik). Hasil belajar ranah psikomotorik disajikan pada tabel berikut.

Tabel 7. Rekapitulasi Hasil Belajar Ranah Psikomotorik Siklus I

\begin{tabular}{cccc}
\hline Kategori & Interval Nilai & Frekuensi (f) & Persentase (\%) \\
\hline Sangat Baik & $90-100$ & 6 & 21 \\
Baik & $78-89$ & 17 & 61 \\
Cukup & $67-77$ & 5 & 18 \\
Kurang & $55-66$ & & \\
Sangat Kurang & $<55$ & & 100 \\
Jumlah & & 28 & \\
Nilai Tertinggi & 100 & \\
Nilai Terendah & 67 & \\
Rerata & 84 & \\
Kategori & Baik &
\end{tabular}

Berdasarkan hasil wawancara dari tiga peserta didik yang mendapatkan nilai tinggi, sedang, dan rendah, menyatakan pembelajaran IPS yang diikuti menarik. Mereka merasa senang jika pelajaran IPS dilaksanakan de ngan diskusi dan kerja kelompok, karena bisa saling membantu. Dengan diberikannya tugas individual maupun kelompok membuat peserta didik merasa tertantang untuk mencari informasi dan wawasan lebih luas lagi. Media yang digunakan guru cocok dengan materi yang diajarkan, sehingga mempermudah memahami materi dan menyenangkan. Adapun kesulitan dalam mengikuti pembelajaran, ketiganya menyatakan waktunya kurang sehingga dalam berdiskusi kurang optimal. Mereka menyarankan untuk pembelajaran berikutnya waktu pertemuannya ditambah dan pembagian kelompok jangan memilih sendiri.

Berdasarkan hasil angket untuk guru, guru telah menerapkan semua komponen 
pendekatan kontekstual dalam pembelajaran IPS dengan menuliskan bentuk/contoh penerapannya. Beberapa kendala yang dihadapi adalah pengelola waktu yang belum tepat dan untuk menyiapkan peralatan (LCD) dibutuhkan waktu sehingga kurang efisien. Saran yang diberikan untuk peningkatan pembelajaran yaitu: (a) dalam merencanakan pelaksanaan pembelajaran hendak lah memperhitungkan waktu dengan tepat agar memudahkan guru dalam mengelola waktu, (b) untuk lebih mengaktifkan peserta didik, pembagian kelompok diperkecil jumlah anggotanya dan secara heterogen.

\section{Hasil Siklus II}

\section{Kualitas Proses Pembelajaran Siklus II}

Kualitas proses pembelajaran dalam penelitian ini dilihat dari kinerja guru dan iklim kelas (keaktivan peserta didik) melalui pengamatan. Pengamatan terhadap terhadap kinerja guru menunjukkan rerata skor 3,83 kategori "Sangat Baik". Kinerja guru tersebut meliputi: (1) kemampuan dalam membuka dan menutup pembelajaran diperoleh rerata 3,95 (Sangat Baik); (2) kemampuan guru dalam menerapkan 7 komponen utama pendekatan kontekstual diperoleh rerata 3,80 (Sangat Baik), dari 7 komponen tersebut semuanya sudah menunjukkan kategori "Sangat Baik"; dan (3) keefektifan penggunaan media pasar, power point, gambar, dan kartu juga sudah menunjukkan kategori "Sangat Baik" $(3,67)$.
Iklim kelas dilihat dari keaktivan peserta didik dalam proses pembelajaran IPS de ngan menggunakan pendekatan kontekstual berbantuan media pasar, power point, kartu, bagan, dan gambar pada siklus II sudah tampak kondusif (Sangat Baik) dengan rerata 3,60 . Kesiapan peserta didik dalam mengikuti pelajaran "Sangat baik", keempat sub-indikator yang dinilai sudah tampak yaitu sebagian besar peserta didik sudah siap di tempat sebelum guru masuk kelas dan dalam kondisi tertib, sudah menyiapkan alat-alat tulis seper ti buku dan pulpen, membawa buku materi IPS yang sudah dipinjami dari sekolah, dan sebagaian besar peserta didik sudah/sedang mempelajari/ mendiskusikan materi yang akan dibahas. Beberapa indikator yang lain juga sudah menunjukkan kondisi "Sangat Baik", seperti: perhatian peserta didik terhadap pembelajaran IPS, pembentukan kelompok belajar yang efektif dan efisien, keaktifan dalam kelompok, keaktifan mengerjakan latihan/tugas, dan membuat rangkuman pelajaran. Keberanian peserta didik dalam bertanya kepada guru dan menjawab pertanyaan, mempresentasikan hasil belajar dan melakukan refleksi terhadap pembelajaran sudah "Baik".

Kualitas proses pembelajaran pada siklus II berdasarkan penggabungan hasil penilaian terhadap kinerja guru dan iklim kelas, diperoleh rerata skor 3,76 dengan kategori "Sangat Baik". Secara ringkas kualitas proses pembelajaran disajikan pada tabel berikut.

Tabel 8. Penilaian Kualitas Proses Pembelajaran Siklus II

\begin{tabular}{lcc}
\hline \multicolumn{1}{c}{ Aspek } & Rerata Skor & Kategori \\
\hline Kinerja guru & 13,83 & Sangat Baik \\
Iklim Kelas & 3,6 & Sangat Baik \\
Rerata & 3,72 & Sangat Baik \\
\hline Rerata & 76 & Cukup \\
\hline
\end{tabular}

\section{Kualitas Hasil Pembelajaran Siklus II}

Hasil belajar ranah kognitif diperoleh dari penilaian tugas individual dan tes hasil belajar. Peserta didik dapat mengumpulkan tugas individual dengan tepat waktu tanpa ada yang terlambat dengan rerata nilai 91,67 (Sangat Baik).

Berdasarkan hasil ulangan harian peserta didik pada siklus II diperoleh rerata nilai 89,29 (Baik). Secara klasikal sudah tuntas, 
karena dari 28 anak yang tuntas belajar 25 anak (89\%), dan masih ada 3 anak (11\%) belum tuntas. Nilai tertinggi sudah mencapai 100 dan terendah 60.

Hasil belajar ranah kognitif merupakan penggabungan penilaian tugas individual
(40\%) dan ulangan harian (60\%) menunjukkan rerata nilai 88,85 (Baik) dan ketuntasan secara klasikal sudah tercapai (93\%). Hasil belajar ranah kognitif secara ringkas disajikan pada tabel berikut.

Tabel 9. Rekapitulasi Hasil Belajar Ranah Kognitif Siklus II

\begin{tabular}{cccc}
\hline Kategori & $\begin{array}{c}\text { Interval } \\
\text { Nilai }\end{array}$ & Frekuensi (f) & Persentase (\%) \\
\hline Sangat Baik & $90-100$ & 17 & 61 \\
Baik & $78-89$ & 9 & 32 \\
Cukup & $67-77$ & 2 & 7 \\
Kurang & $55-66$ & & \\
Sangat Kurang & $<55$ & & 100 \\
Jumlah & & 28 & \\
Nilai Tertinggi & 100 & \\
Nilai Terendah & 69 & \\
Rerata & 88,85 & \\
Ketuntasan & $93 \%$ & \\
\hline
\end{tabular}

Penilaian hasil belajar ranah afektif dilakukan secara autentik yaitu terhadap kecakapan sosial dan sikap peserta didik terhadap pembelajaran IPS. Hasil penilaian kecakapan sosial diperoleh rerata nilai 79 dengan kategori "Baik". Secara ringkas hasil penilaian kecakapan sosial peserta didik sebagai berikut.

\section{Tabel 10. Rekapitulasi Penilaian Kecakapan Sosial Siklus II}

\begin{tabular}{ccc}
\hline Aspek & Rerata Skor & Kategori \\
\hline Kerja sama & 79 & Baik \\
Tanggung jawab & 76 & Cukup \\
Tenggang rasa & 82 & Baik \\
Rerata & 79 & Baik \\
\hline
\end{tabular}

Sikap peserta didik terhadap pembelajaran IPS diperoleh rerata skor 86 dengan kategori "Baik". Sikap peserta didik terhadap pembelajaran IPS secara ringkas ditunjukkan pada tabel berikut.

Tabel 11. Rekapitulasi Penilaian Sikap Peserta Didik terhadap Pembelajaran IPS Siklus II

\begin{tabular}{lcc}
\hline \multicolumn{1}{c}{ Indikator } & Rerata Skor & Kategori \\
\hline Memandang penting pelajaran IPS & 86 & Baik \\
Menyenangi pembelajaran IPS & 85 & Baik \\
Memandang penting penggunaan media pembelajaran & 86 & Baik \\
Rerata & 86 & Baik \\
\hline
\end{tabular}


Hasil belajar ranah afektif siklus II berdasarkan penggabungan penilaian kecakapan sosial dan sikap peserta didik terhadap pembelajaran IPS, maka diperoleh rerata nilai sebesar 82 dalam kategori "Baik". Hasil Belajar ranah afektif secara ringkas disajikan pada tabel berikut.

Tabel 12. Rekapitulasi Hasil Belajar Ranah Afektif Siklus II

\begin{tabular}{ccccc}
\hline Kategori & $\begin{array}{c}\text { Interval } \\
\text { Nilai }\end{array}$ & Frekuensi (f) & Persentase (\%) & Persentase (\%) \\
\hline Sangat Baik & $90-100$ & 2 & 7 & 61 \\
Baik & $78-89$ & 21 & 75 & 32 \\
Cukup & $67-77$ & 5 & 18 & 7 \\
Kurang & $55-66$ & & & \\
Sangat Kurang & $<55$ & & 100 & \\
Jumlah & & 95 & & \\
\hline Nilai Tertinggi & 67 & & \\
Nilai Terendah & 82 & \\
Rerata & Baik & \\
Kategori &
\end{tabular}

Selama proses pembelajaran Siklus II, guru melaksanakan penilaian autentik melalui kerja kelompok (ranah psikomotorik). Kerja kelompok sebanyak dua kali yaitu: pengamatan di pasar dan mengidentifikasi ciri-ciri macam-macam pasar. Hasil penilaian diperoleh rerata nilai 98 atau (Sangat Baik). Hasil belajar ranah psikomotorik disajikan pada tabel berikut.

Tabel 13. Rekapitulasi Hasil Belajar Ranah Psikomotorik Siklus II

\begin{tabular}{|c|c|c|c|c|}
\hline Kategori & $\begin{array}{c}\text { Interval } \\
\text { Nilai }\end{array}$ & Frekuensi (f) & Persentase (\%) & Persentase (\%) \\
\hline Sangat Baik & $90-100$ & 28 & 100 & 61 \\
\hline Baik & $78-89$ & & & 32 \\
\hline Cukup & $67-77$ & & & 7 \\
\hline Kurang & $55-66$ & & & \\
\hline Sangat Kurang & $<55$ & & & \\
\hline Jumlah & & 28 & 100 & 100 \\
\hline Nilai Ter & & 100 & & \\
\hline Nilai Ter & & 92 & & \\
\hline Rerata & & 98 & & \\
\hline Kategori & \multicolumn{3}{|c|}{ Sangat Baik } & \\
\hline
\end{tabular}

Berdasarkan hasil wawancara dari tiga peserta didik yang mendapat nilai tinggi sedang, dan rendah menyatakan pembelajaran IPS yang diikuti sangat menarik dan menye nangkan. Alasan ketertarikan mereka karena bisa melihat obyek secara langsung, menga mati, lebih jelas dan bisa refreshing sambil berbelanja. Mereka merasa senang jika pelajaran IPS dilaksanakan dengan diskusi dan kerja kelompok, karena bisa saling membantu, dapat berinteraksi dengan teman lain, dan melatih tanggung jawab serta keberanian untuk bertanya dan mengemukakan pendapat. Sebagian besar peserta didik merasa lebih 
cocok dengan pembagian kelompok yang heterogen. Dengan diberikannya tugas individual maupun kelompok membuat peserta didik merasa tertantang untuk mencari informasi dan wawasan lebih luas lagi.

Media pasar yang digunakan guru cocok dengan materi yang diajarkan, sehingga mempermudah memahami materi dan menyenangkan. Pembelajaran pada siklus II tidak ada kendala yang berarti, mereka merasa sudah pas.

Berdasarkan hasil angket untuk guru, guru telah menerapkan semua komponen pendekatan kontekstual dalam pembelajaran secara baik dengan disertai bentuk/ contoh penerapannya. Tidak ada kendala yang berarti dalam penerapan pembelajaran kontekstual berbantuan media pasar, power point, kartu, bagan, dan gambar, hanya untuk menyiapkan peralatan LCD masih membutuhkan waktu karena harus mengambil dan mengembalikan ke ruang multi media.

Peningkatan kualitas proses pembelajaran IPS dalam penelitian ini, pada prinsipnya adalah hasil dari penerapan pendekatan kontekstual secara konsisten dengan menggunakan media power point, kartu, bagan, gambar, dan pasar. Semakin kuat penerapan 7 komponen pendekatan kontekstual, maka akan semakin meningkat iklim kelasnya (keaktivan peserta didik), sehingga kualitas proses pembelajarannya meningkat. Hal ini dapat dibuktikan dari hasil pengamatan terhadap kinerja guru dan iklim kelas. Kualitas proses pembelajaran pada pratindakan menunjukkan rerata skor 1,68 (Kurang), setelah dilakukan tindakan siklus I rerata skor meningkat menjadi 2,98 (Baik), dan setelah penerapan pendekatan kontekstual diperkuat lagi dengan ditambah media pasar, maka pada siklus II hasilnya meningkat lagi menjadi 3,72 (Sangat Baik).

Data peningkatan kualitas proses pembelajaran dari pra tindakan sampai siklus II disajikan pada grafik berikut.

Berdasarkan hasil penelitian, setelah dite rapkannya pendekatan kontekstual dengan bantuan media power point, kartu, bagan, gambar, dan pasar pada pembelajaran IPS berdampak pada peningkatan hasil belajar secara komprehensif.

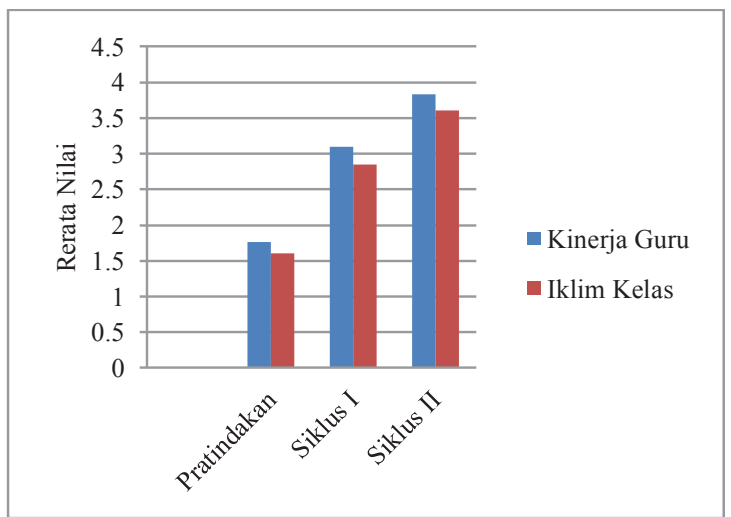

\section{Gambar 1. Grafik Peningkatan Kualitas Proses Pembelajaran}

Hasil belajar pada ranah kognitif yang meliputi nilai ulangan harian dan nilai tugas individual mengalami peningkatan. Sebelum dilakukan tindakan, nilai rerata 76,43, ketuntasan kelas belum tercapai karena persentase ketuntasan masih dibawah 50\% yaitu 46\%. Setelah dilakukan tindakan dengan menerapkan pendekatan kontekstual berbantuan media, pada siklus I nilai rerata menga lami peningkatan menjadi 85,71, ketuntasan kelas mencapai 89\%. Setelah dilakukan perbaikan pada siklus II meningkat lagi, nilai rerata menjadi 88,84 dan ketuntasan mencapai 93\%. Dengan demikian target ketuntasan secara klasikal sudah tercapai. Peningkatan kualitas hasil belajar ranah kognitif disajikan pada grafik berikut.

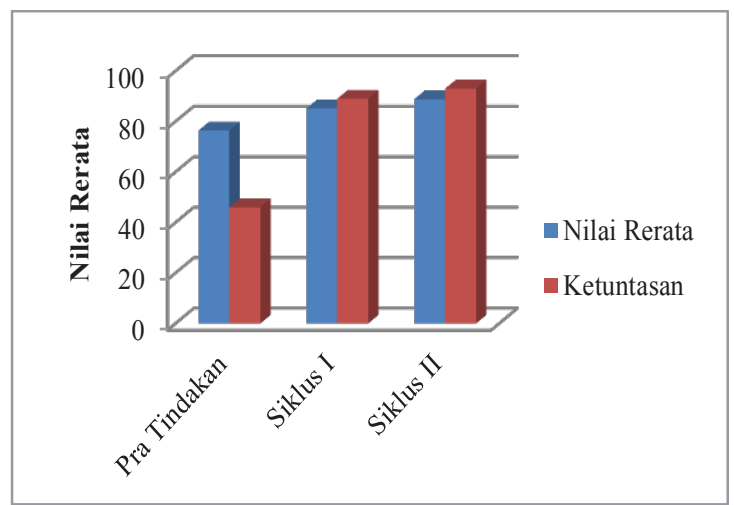

Gambar 2. Grafik Peningkatan Hasil Belajar Ranah Kognitif 
Peningkatan ranah afektif yang merupakan penggabungan dari penilaian kecakapan sosial dan sikap peserta didik dari siklus I ke siklus II tidak begitu tinggi, karena pada siklus I sudah menunjukkan hasil "Baik" yaitu rerata skor 79. Hasil belajar ranah afektif pada siklus II meningkat 3 angka sehingga rerata skor menjadi 82 (Baik). Walaupun belum mencapai skor maksimal, namun penelitian tindakan kelas ini dirasa sudah berhasil karena sudah mencapai target yang ditentukan yaitu sikap peserta didik menunjukkan kategori "Baik". Peningkatan hasil belajar ranah afektif peserta didik terhadap pembelajaran IPS disajikan pada grafik berikut.

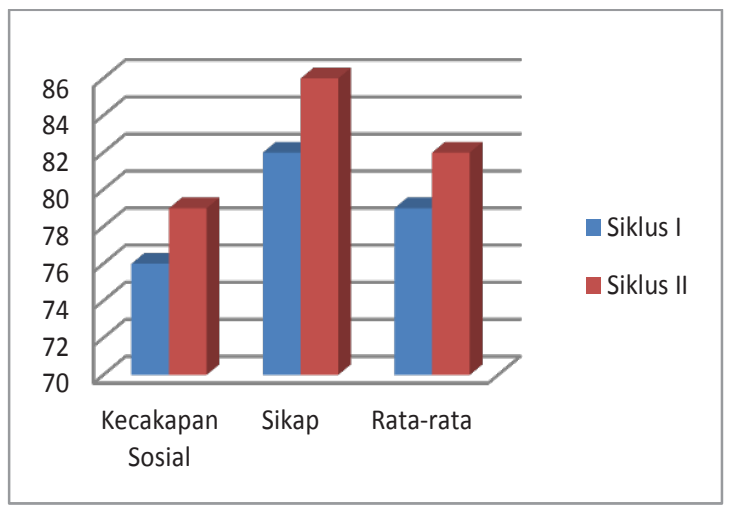

\section{Gambar 3. Grafik Peningkatan Hasil Belajar Ranah Afektif}

Peningkatan kualitas hasil belajar ranah psikomotor yang diperoleh dari hasil kerja kelompok, pada siklus I belum mencapai hasil yang optimal, peserta didik belum bisa mengefektifkan kerja kelompok terutama dalam pembagian tugas dan mengelola waktu. Kelancaran dalam mengkomunikasikan hasil kerja kelompok juga masih kurang optimal karena belum berpengalaman. Pada siklus II meningkat menjadi "Sangat Baik" hal ini karena peserta didik sudah tidak canggung lagi dalam mengkomunikasikan hasil kerja kelompok dan mengefektifkan kerja kelompok dengan baik. Peningkatan kualitas hasil belajar ranah psikomorik disajikan pada grafik berikut.

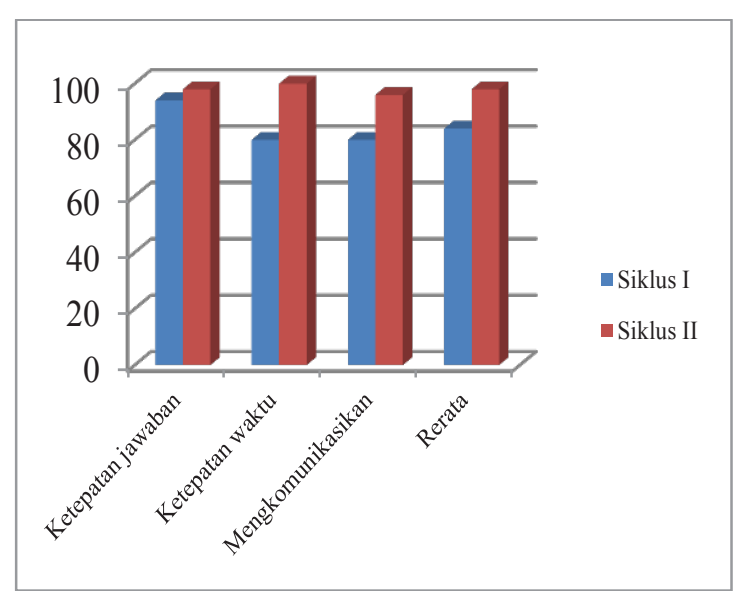

\section{Gambar 4. Grafik Peningkatan Hasil Belajar Ranah Psikomotorik}

Penelitian tindakan kelas pembelajaran IPS dengan menerapkan pendekatan konteks tual berbantuan media powerpoint, kartu, bagan, gambar, dan pasar mulai dari siklus I sampai siklus II berjalan sesuai dengan yang direncanakan, tidak ada kendala yang berarti hanya pada kemampuan guru yang berkaitan dengan teknik dalam menerapkan pendekatan kontekstual dan pengelolaan waktu yang kurang tepat dalam pembelajaran yang terjadi pada siklus I. Hal ini karena guru baru pertama kali menggunakan pendekatan kontekstual. Selain itu, ketersedian peralatan LCD yang tidak berada di dalam kelas sehingga untuk menyiapkannya membutuhkan waktu. Setelah dilakukan refleksi dan diadakan perbaikan dalam perencanaan dan pelaksanaan tindakan, maka pada siklus II kendala tersebut dapat diminimalisasi.

Keberhasilan penelitian ini tidak lepas dari adanya beberapa faktor yang menunjang ketercapaian tujuan yang diharapkan. Bebe rapa faktor pendorong tersebut antara lain: (1) input peserta didik yang baik dilihat dari nilai rata-rata NEM minimal 7,5, (2) lingku ngan sekolah yang kondusif untuk kegiatan belajar yang ditunjang dengan perpustakaan, laboratorium multimedia dan area hotspot yang bisa diakses oleh semua warga sekolah, (3) motivasi yang tinggi dari kolaborator untuk meningkatkan kualitas pembelajaran, ditunjukkan dengan adanya upaya mengatasi 
kelemahan-kelemahan yang terjadi pada siklus I, dan (4) letak sekolah dekat dengan pasar modern dan pasar tradisional yang dapat digunakan sebagai media untuk menunjang proses pembelajaran.

Beberapa keterbatasan dalam penelitian ini adalah tidak semua aspek masukan ins trumental (pendidik/kinerja guru, kurikulum, iklim kelas, materi, media pembelajaran, dan fasilitas) dapat diteliti, karena adanya beberapa keterbatasan dan kriteria penilaian dalam penelitian ini tidak sama. Untuk me ngukur kualitas pembelajaran menggunakan skala 1 sampai dengan 4, sedangkan untuk mengukur kualitas hasil belajar mengguna kan skala 1 sampai dengan 100.

\section{SIMPULAN}

Dari hasil penelitian diperoleh kesimpulan: (1) penerapan pendekatan kontekstual berbantuan media powerpoint, kartu, bagan, gambar, dan pasar dalam pembelajaran IPS di kelas VIII.5 SMPN 1 Wiradesa mampu memunculkan tujuh komponen pendekatan kontekstual yaitu kontruktivisme (constructivism), menemukan (inquiry), bertanya (questioning), masyarakat belajar (learning community), pemodelan (modeling), refleksi (reflection), dan penilaian autentik (autentic assessment) dengan kadar yang semakin meningkat. Sebelum tindakan menunjukkan kategori "Sangat Kurang". Setelah dilakukan tindakan pada siklus I meningkat menjadi "Baik" dan pada siklus II menjadi "Sangat Baik". (2) penerapan pendekatan kontekstual berbantuan media power point, kartu, bagan, gambar, dan pasar dalam pembelajaran IPS di kelas VIII.5 SMPN 1 Wiradesa dapat meningkatkan kualitas pembelajaran, baik dari segi proses maupun hasil belajar secara komprehensif. Kualitas proses pembelajaran yang diukur dengan skala 1-4, sebelum dilakukan tindakan menunjukkan rerata skor 1,70 (Kurang). Pada siklus I diperoleh rarata skor 3,05 (Baik), dan pada siklus II rerata skor meningkat menjadi 3,76 (Sangat Baik). Pe ningkatan kualitas hasil belajar yang diukur dengan skala 0-100 dibuktikan dari sebelum tindakan hasil belajar ranah kognitif menunjukkan rerata nilai 76,43 dengan ketuntasan kelas $46 \%$. Setelah dilakukan tindakan pada siklus I diperoleh rerata nilai 85,17 dengan ketuntasan kelas $83 \%$, dan pada siklus II rerata nilai meningkat lagi menjadi 88,84 dengan ketuntasan kelas 93\%. Hasil belajar ranah afektif menunjukkan kecakapan sosial dan sikap positif peserta didik terhadap pembelajaran IPS pada siklus I rerata nilai 79 dan siklus II 82, keduanya menunjukkan kategori "Baik". Hasil belajar ranah psikomotorik mengalami peningkatan pada siklus I menunjukkan rerata niali 84 dengan kategori 'Baik" dan pada siklus II menjadi 98 "Sangat Baik", (3) penerapan pendekatan kontekstual berbantuan media power point, kartu, bagan, gambar, dan pasar di kelas VIII.5 SMPN 1 Wiradesa mulai dari siklus I sampai siklus II tidak ada kendala yang berarti hanya pada kemampuan guru yang berkaitan dengan teknik dalam menerapkan pendekatan kontekstual dan pengelolaan waktu yang kurang tepat dalam pembelajaran yang terjadi pada siklus I. Setelah dilakukan refleksi dan diadakan perbaikan, maka pada siklus II kendala tersebut dapat diminimalisasi, dengan didukung beberapa faktor pendorong antara lain: input peserta didik yang baik, lingkungan sekolah yang kondusif, dan motivasi yang tinggi dari guru untuk meningkatkan kualitas pembelajaran.

Berdasarkan simpulan di atas disarankan kepada guru IPS hendaknya dapat memanfaatkan hasil penelitian ini sebagai alternatif pembelajaran IPS. Kepada SMP N 1 Wiradesa agar menyelenggarakan pelatihan dan pendidikan untuk guru-guru IPS terkait dengan peningkatan kompetensi guru dalam pe nguasaan materi, pedagogik, dan pengunaan media pembelajaran. Bagi para peneliti yang tertarik melakukan penelitian tindakan kelas disarankan untuk melakukan penelitian lanjutan dengan lebih memperdalam pemahaman pendekatan kontekstual dan penggunaan media yang tepat sehingga dapat melengkapi dan menyempurnakan hasil. 


\section{UCAPAN TERIMA KASIH}

Dalam penulisan artikel jurnal ini, penulis sangat dibantu oleh banyak pihak khususnya dosen pembimbing. Untuk itu, dalam kesempatan ini penulis menyampaikan terima kasih kepada yang terhormat Pembimbing tesis, yang telah banyak membantu, mengarahkan dan membimbing sehingga artikel jurnal ini dapat terselesaikan.

\section{DAFTAR PUSTAKA}

Berns, R.G. and Erickson, P. M. 2001. Contextual Teaching and Learning The Highlight Zone: Research @ Work No. 5. Diambil pada tanggal 4 April 2013, dari http:// www.nccte,org/publications/ infosynthesis/highlightzone/ highlight05/index. asp.

Harimurti, E. 2011. Pendekatan Kontekstual Dengan Teknik Rangsang Gambar Dalam Upaya Meningkatkan Kemampuan Bercerita. Didaktikum: Jurnal Penelitian Tindakan Klas, 7 (2), 33-41.

Kemmis, S. \& Taggart, Mc. R. 1990. The Action Research Planner. Burwood: Deakin University Press.
Komalasari, K. 2011. Pembelajaran Kontekstual: Konsep dan Aplikasi. Bandung: Refika Aditama.

Mulyasa, E. 2008. Kurikulum Berbasis Kompetensi: Konsep, Karakteristik, dan Implementasi. Bandung: Remaja Rosdakarya.

Muslich, Masnur. 2009. KTSP Pembelajaran Berbasis Kompetensi dan Kontekstual. Jakarta: Bumi Aksara.

Sanjaya, W. 2010. Strategi Pembelajaran Berorientasi Standar Proses Pendidikan. Jakarta: Kencana Prenada Media Group.

Setyati, R. 2011. Peningkatan Aktivitas dan Hasil Belajar Kalor Melalui Pendekatan Kontekstual Berbantuan Concept Cartoon Bagi Siswa Kelas VII.6 SMP 2 Blora Semester Genap Tahun Pelajaran 2010/ 2011. Metodika: Jurnal Pendidikan Dasar, 1 (3), 71-77.

Solihatin, E. \& Raharjo. 2011. Cooperative Learning: Analisis Model Pembelajaran IPS. Jakarta: Bumi Aksara.

Sukiman. 2012. Pengembangan Media Pembelajaran. Yogyakarta: Pustaka Insan Madani.

Widoyoko, E.P. 2013. Evaluasi Program Pembelajaran: Panduan Praktis Bagi Pend-dik Dan Calon Pendidik. Yogyakarta: Pustaka Pelajar. 